\title{
PENGARUH SCRABBLE VERSUS PETUALANGAN MAHARAJA DAN MOTIVASI BELAJAR TERHADAP KEMAMPUAN MEMBACA ANAK DISLEKSIA
}

\author{
Insiyah, Iskandar Wiryokusumo, Achmad Noor Fatirul \\ Teknologi Pendidikan, Pascasarjana, Universitas PGRI Adibuana Surabaya, \\ Jl. Dukuh Menanggal XII No.17, Surabaya \\ E-mail: insiyah642@gmail.com
}

\begin{abstract}
This study aims to determine the difference between scrabble versus maharaja adventure on the reading motivation of dyslexic students, knowing the difference between high and low motivation on the reading ability of dyslexic students, and knowing the interaction between play and motivation on the reading ability of dyslexic students. Research methods using experiments. The sample of this study were 8 students. The sampling technique uses purposive sampling technique. Data analysis technique used twoway Anava with a significance value of $\alpha=0.05$. The results of the study concluded that there were differences in scrabble versus maharaja adventure games on the reading motivation of dyslexic students, there were differences in high and low motivation on the reading ability of dyslexic students, and there was an interaction between games and motivation on the reading ability of dyslexic students.
\end{abstract}

Keywords: Scrabble, Maharaja's Adventure, Learning Motivation, Reading Ability, Dyslexia.

\begin{abstract}
Abstrak
Penelitian ini bertujuan untuk mengetahui perbedaan scrabble versus petualangan maharaja pada motivasi membaca siswa disleksia, mengetahui perbedaan motivasi tinggi dan rendah pada kemampuan membaca siswa disleksia, dan mengetahui interaksi antara permainan dan motivasi pada kemampuan membacasiswa disleksia. Metode Penelitian menggunakan eksperimen. Sampel penelitian ini sebanyak 8 siswa. Teknik pengambilan sampel menggunakan teknik purposive sampling.Teknik analisis data menggunakan Anava dua jalur dengan nilai signifikansi sebesar $\alpha=$ 0,05 . Hasil penelitian menyimpulkan bahwa ada perbedaan scrabble versus permainan petualangan maharaja pada motivasi membaca siswa disleksia, ada perbedaan motivasi tinggi danrendah pada kemampuan membaca siswa disleksia, dan ada interaksi antara permainan dan motivasi pada kemampuan membacasiswa disleksia.
\end{abstract}

Kata kunci: Scrabble, Petualangan Maharaja, Motivasi Belajar, Kemampuan Membaca, Disleksia 
Setiap warga Negara mendapatkan hak yang sama untuk memperoleh pendidikan yang bermutu, sebagaimana yang termaktub dalam Undang-Undang Sistem Pendidikan Nasional No 20 pasal 5 ayat 1 tahun 2003. Dengan tujuan pendidikan sebagaimana yang dituangkan dalam Undang-undangn di atas, setiap peserta didik memerlukan kemampuan dan pengetahuan dasar sebagai langkah awal untuk siap menerima bermacam informasi maupun pengetahuan yang akan disampaikan oleh guru. Kemampuan menggunakan adalah kemampuan dasar yang wajib dikuasai peserta didik, dan kemampuan ini adalah sangat penting. Kemampuan membaca bagi anak akan membantu anak untuk menerima ataupun mengolah pengetahuan yang diterima (Abdurahman, 2009).

Perkembangan anak dapat mengalami hambatan belajar dengan berbagai variasi penyebabnya, salah salah satunya adalah disleksia. Disleksia diartikan sebagai sebuah bentuk kesulitan untuk memahami komponen-komponen kata di dalam sebuah kalimat. Kesulitan ini memperlihatkan keterlambatan dalam perkembangan bahasa seseorang dan berdampak kemampuan menulis maupun mengeja. Disleksia merupakan kelainan dalam belajar yang khusus, sehingga tidak dipengaruhi oleh tingkat intelegensi seseorang. Disleksia juga diartikan kesulitan untuk memahami sebuah simbol maupun kode, termasuk dalam hal fonologi yaitu pengucapan sebuah kata (Elbro, 2010).
Setelah dilakukan observasi dan wawancara yang dilakukan di sebuah Sekolah Dasar Negeri Mulyodadi dan Sekolah Dasar Negeri Sawocangkring Kec. Wonoayu awal tahun pelajaran dari beberapa kelas baik kelas kecil dan besar, didapatkan fakta empiri berupa kemampuan membaca yang rendah pada beberapa siswa. Hal ini tampak pada beberapa kesalahan dalam membaca yaitu dalam mengucapkan bunyi huruf diftong (ng,ny), urutan yang salah dalam menyusun kata, kesalahan menulis angka 6 menjadi 9, kesalahan menulis huruf d yang kerap salah dan dituliskan b. Kesalahan berikutnya dalam mengganti pengucapan kata, kehilangan huruf tertentu, dan keterlambatan pada kecepatan membaca. Dengan demikian beberapa siswa memiliki kemampuan membaca yang rendah.

Dari permasalahan tersebut maka perlu dicarikan solusi yang tepat untuk dapat mengatasinya sehingga aktivitas belajar, pemahaman, dan hasil belajar peserta didik dalam membaca dan menulis bagi anak penyandang disleksia. Permasalahan di atas menjadi dasar peneliti untuk mengadakan penelitian yang berjudul 'Pengaruh permainan Scrabble versus Permainan petualangan maharaja dan motivasi terhadap kemampuan membaca pada anak disleksia SDN Mulyodadi dan SDN Sawocangkring WonoayuSidoarjo"

Sebagaimana uraian rumusan masalah di atas, maka dapat disusun tujuan penelitian sebagai berikut : (1) Mengetahui perbedaan dari model permainan Scrabble versus permainan petualangan maharaja terhadap 
motivasi membaca pada siswa penyandang disleksia di SDN Mulyodadi dan SDN Sawocangkring Wonoayu. (2) Mengetahui perbedaan motivasi tinggi dan motivasi rendah terhadap kemampuan membaca siswa penyandang disleksia SDN Mulyodadi dan SDN Sawocangkring Wonoayu. (3) Mengetahui interaksi antara permainan dan motivasi terhadap kemampuan membaca siswa yang menyandang disleksia di SDN Mulyodadi dan SDN Sawocangkring Wonoayu.

\section{Untuk}

menghindari

kesalahpahaman dan perbedaan pemahaman terkait beberapa istilah, maka akan dijelaskan beberapa istilah yang digunakan sebagai berikut: (a) Permainan Scrabble, (b)Permainan petualangan Maharaja, dan (c) Motivasi belajar.

Scrabble adalah permainan kata yang menggunakan papan dan dimanfaatkan sekolah untuk menunjang kurikulum kegiatan akademik siswa. Scrabble adalah media untuk mengembangkan kemampuan berbahasa (Hinebaugh, J., 2009). Teknik permainannya mirip dengan permainan scrabble pada umumnya, namun ada modifikasi pada aturannya dan menggunakan bahasa Indonesia. Scrabble merupakan permainan dalam menyusun kata yang menggunakan papan yang dilakukan oleh dua hingga empat orang (Ismail, 2009). Permainan ini biasa disebut "spersgame" atau "funworder". Dalam melakukan permainan, setiap orang tidak hanya mengandalkan perbendaharaan kata, tetapi harus memiliki cara dan strategi dalam menaklukkan lawan (Mulyono, 2012).

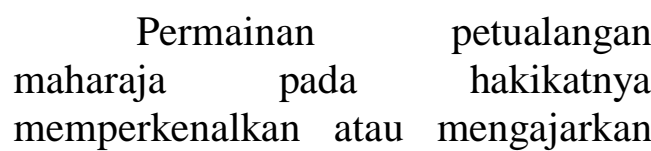
anak membaca itu sejak dini dengan memperhatikan syarat-syarat fitrah perkembangan anak. Fitrah anak itu rasa ingin tahunya lebih tinggi, bergerak bebas tanda sehat, sering bertanya tanda kognisi berkembang. Syarat - syarat memperkenalkan keaksaraan awal yang sehat sesuai perkembangan fitrah anak, permainan Petualangan Maharaja seperti bermain ular tangga pada umumnya hanya saja ukuran nya lebih besar karena anak-anak yang menjadi Pionnya dalam bermain dalam permainan ini banyak sekali.

Motivasi adalah sesuatu yang menjadi dorongan seseorang untuk melakukan sesuatu (Sari, 2013). Motivasi membaca dapat diajarkan sejak dini pada anak-anak, sehingga memiliki kebiasaan yang baik dalam membaca. Membaca memberi manfaat yang cukup besar dalam kehidupan dan memberi motivasi untuk membaca terutama pada penyandang disleksia sehingga tercipta kebiasaan dan memperbaiki kemampuan membaca.

Dalam permainan ini peneliti menggunakan metode Fernald. Metode ini memanfaatkan kemampuan multisensoris yang meliputi penglihatan (Visual), pendengaran (Auditory), gerak (Kinestetic), dan perabaan (Tactile) yang mencakup tiga tahapan, yaitu: a) menelusuri contoh tulisan dengan jari (Tactile dan Kinesthetic). b) melihat (visual) (c) mengucapkannya (auditory). Permainan Scrabble dan Petualangan Maharaja dapat digunakan sebagai media pembelajaran untuk membaca 
karena mengandung konsep VAKT. Metode Fernald dapat meningkatkan kemampuan baca bagi anak disleksia (Zunus, 2017). Kemampuan melihat (visual) dapat digunakan mempelajari beberapa kata. Dalam permainan petualangan maharaja siswa diajak bergerak lebih banyak sehingga anak bebas berekspresi dalam bermainnya.

Disleksia berasal dari kata Yunani yaitu "dys" yang memiliki arti kesulitan dan "leksia" yang memiliki arti kata-kata. Oleh sebab itu disleksia didefinisikan sebagai kesulitan untuk mengolah kata-kata. Disleksia menurut asosiasi Disleksia Internasional tahun 1994 merupakan sebuah gangguan saraf dan memiliki kecenderungan diturunkan dalam sebuah keluarga. Kecenderungan kebiasaan yang diberlakukan dalam keluarga akan mempengaruhi cara menerima dan memproses bahasa. Tingkat gangguan sendiri dapat bermacam-macam, yaitu meliputi kesulitan untuk memahami dan mengekspresikan bahasa. Proses mengucapkan (fonologi) dalam membaca, mengeja dan menulis dengan tangan akan mengalami kesulitan dan berpengaruh pada kemampuan aritmatik (Diba, 2019).

Bryan mengungkapkan bahwa disleksia merupakan hambatan dalam belajar komponen kata serta kalimat,hambatan ini akan menyebabkan kelambatan perkembangan bahasa dan berdampak pada kemampuan mengeja dan menulis (Soeisniwati, 2012).

\section{METODE}

Jenis penelitian ini merupakan penelitian kuantitatif, bentuk penelitian dilakukan secara sistematis, terstruktur, serta terperinci dengan penggunaan angka, tabel untuk memaparkan hasil data yang diperoleh. Penelitian ini membandingkan antara permainan scrabble dan permainan petualangan maharaja dan motivasi belajar terhadap membaca siswa Disleksia.

Tabel1. Rancangan penelitian

\begin{tabular}{lcc}
\hline & \multicolumn{2}{c}{ Media } \\
\cline { 2 - 3 } Motivasi & $\begin{array}{c}\text { Scrable } \\
\text { (X1) }\end{array}$ & $\begin{array}{c}\text { Petualangan } \\
\text { Maha Raja } \\
\text { (X2) }\end{array}$ \\
\hline $\begin{array}{l}\text { Tinggi } \\
\text { (T) }\end{array}$ & X1 T & X2 T \\
$\begin{array}{l}\text { Rendah } \\
(\mathrm{R})\end{array}$ & X1 R & X2 R \\
\hline
\end{tabular}

Keterangan :

X1 T: Kemampuan membaca siswa disleksia yang menerapkan penggunaan permainan Scrabble yang memiliki tingkat motivasi membaca tinggi.

X1 R: Kemampuan membaca siswa disleksia yang menerapkan penggunaan permainan Scrabble yang memiliki tingkat motivasi membaca rendah.

X2 T: Kemampuan membaca siswa disleksia yang menerapkan penggunaan permainan Petualangan maharaja yang memiliki tingkat motivasi membaca tinggi.

X2 R: Kemampuan membaca siswa disleksia yang menerapkan penggunaan permainan Petualangan maharaja yang memiliki tingkat motivasi membaca rendah.

Populasi dalam penelitian adalah SDN Mulyodadi 3 (tiga) siswa disleksia. SDN Sawocangkring 5 (lima) siswa disleksia, jadi jumlah 
keseluruhan 8 (delapan ) siswa. Dalam mengambil sampel digunakan teknik Non probabilitas yang melakukan pengambilan sampel secara purposive (purposive sampling). pengambilan subjek tidak berdasarkan atas strata, random atau wilayah, akan tetapi berdasarkan untuk mencapai tujuan tertentu (Arikunto, 2014). Pemilihan subyek dilakukan melalui proses penyaringan untuk mengetahui kemampuan membaca siswa sebelum dikenakan perlakuan dengan cara siswa diminta membaca kata sederhana. Selanjutnya siswa diminta membaca kalimat sederhana melalui tindakan permainan scrabble dan petualangan maharaja.

Pengambilan sampel dalam penelitian ini dilakukan eksperimen pada anak disleksia dari SDN Mulyodadi dan SDN Sawocangkring keduanya di berikan permainan yang sama yaitu scrabble dan petualangan maharaja dimana kedua permainan itu akan di ketahui mana yang lebih mudah untuk dimainkan sehingga dapat memberikan motivasi membaca pada anak disleksia.

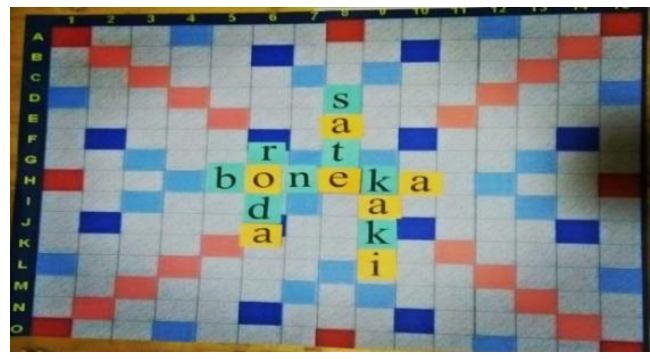

Gambar1. Papan permainan Scrabble yang sudah dimodifikasi

Papan permainan Scrable yang sudah dimodifikasi sebagai alat untuk menyusun kata sesuai dengan petunjuk dalam permainan. Sebagai pembanding berikutnya adalah kartu petualangan maharaja. Kartu ini digunakan untuk mempermudah pemahaman dalam memadukan unsur kata dan gambar.

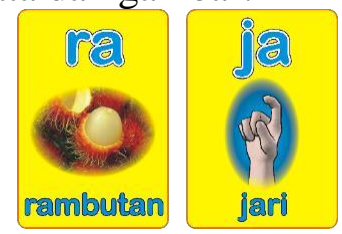

\section{Gambar 2. Kartu permainan petualangan maharaja}

Instrumen penelitian merupakan alat yang dipakai untuk mendapatkan data penelitian. Dalam penelitian kuantitatif instrument penelitian ini menggunakan instrument tes. Tes yang dipakai mencakup: tes pengenalan kata dan tes dalam membaca kalimat. Tes kemampuan membaca menggunakan pretest, posttest, maupun pemberian perlakuan. Perlakuan diberikan menggunakan media permainan scrabble versus petualangan maharaja. Kalimat dalam pretest maupun posttest adalah sama, sehingga terlihat perubahan sebelum perlakuan dan setelah perlakuan.

Angket digunakan untuk menjaring motivasi siswa disleksia dalam membaca. Dalam hal ini peneliti menggunakan angket tertutup. Data-data dianalisis menggunakan Statistik Anova dua jalan ( Two -Way Anova) untuk mengetahui perbedaan rata-rata kelompok eksperimen dan mengetahui pengaruh serta interaksinya

\section{HASIL DAN PEMBAHASAN}

Langkah awal sebelum uji Anava adalah uji normalitas. Hasil 
uji normalitas dengan metode saphiro-wilk didapatkan nilai sig 0,062, dengan ketentuan berdistribusi normal apabila didapat nilai sig> 0,05 , sehingga data yang diperoleh adalah berdistribusi normal. Berikutnya dilakukan uji Levene's untuk mendapatkan homogenitas data didapatkan hasil sig. 0,07 ( sig > 0,05) maka data dapat dinyatakan homogen. Dengan demikian data yang diperoleh adalah homogen dan dapat dilanjutkan untuk uji Anava dua jalur. Dalam pengujian hipotesis pertama pengujian perbedaan permainan scrabble versus Petualangan Maharaja terhadap kemampuan membaca siswa penyandang disleksia menggunakan uji anava dua jalur diperoleh data nilai signifikansi sebesar 0,027. Dasar dalam pengambilan keputusan dalam uji Anava dua jalur ini, jika nilai sig< 0,05 , maka ada perbedaan permainan Scrabbleversus petualangan Maharaja terhadap kemampuan membaca anak disleksia. Dengan demikian ada perbedaan permainan Scrabbleversus petualangan Maharaja terhadap kemampuan membaca anak disleksia.

Pengujian hipotesis kedua membahas tentang pengaruh perbedaan motivasi tinggi dan motivasi rendah terhadap kemampuan membaca anak disleksia. Keputusan yang diambil dalam uji Anava dua jalur ini, apabila sig $<0,05$ maka ada pengaruh antara siswa yang bermotivasi tinggi dan siswa yang motivasinya rendah terhadap kemampuan membaca anak disleksia. Uji hipotesis kedua diperoleh nilai alpha sebesar 0,000 (sig. $<0,05)$ yang artinya ada pengaruh perbedaan motivasi tinggi dan motivasi rendah terhadap kemampuan membaca anak disleksia.

Pembahasan uji hipotesis ketiga adalah interaksi antara permainan dan motivasi belajar terhadap kemampuan membaca anak disleksia. Dasar dalam pengambilan keputusan dalam uji Anava dua jalur ini, jika nilai sig $<0,05$ maka ada interaksi antara permainan dan motivasi belajar terhadap kemampuan membaca anak disleksia. Hasil perhitungan uji Anava dua jalur diperoleh nilai signifikansi sebesar 0,049 yang artinya $0,049<0,05$ sehingga dapat disimpulkan bahwa ada interaksi antara permainan dan motivasi terhadap kemampuan membaca siswa disleksia.

Penelitian ini dilakukan pada sekolah inklusif, artinya sekolah yang memiliki anak berkebutuhan khusus atau ABK. Mereka dari kelas yang bervariasi, SDN Mulyodadi terdapat siswa disleksia di kelas II, III dan kelas IV masing masing satu anak. Sedangkan dari SDN Sawocangkring dari kelas I satu anak, kelas III satu anak dan kelas IV tiga anak. Penelitian ini dibantu oleh shadow teacherl guru pendamping khusus (GPK). Penelitian ini dilakukan setiap hari kamis karena sesuai dengan jadwal yang ada di ruang sumber, ruang sumber yang dimaksud adalah ruang yang dibuat untuk mengembangkan pendidikan khusus dan dapat dipakai semua anak, terutama pada anak yang memiliki berkebutuhan khusus

Untuk meningkatkan motivasi membaca terhadap siswa disleksia peneliti memberikan dua permainan yaitu Scrabble versus Petualangan maharaja, dari dua permainan ini manakah yang lebih meningkatkan 
motivasi siswa dalam membaca dengan baik. Permainan Scrabble yang sudah dimodifikasi diterapkan sebanyak 2 kali permainan. Adapun permainan ini terdiri atas dua tahap. Pada tahap awal setiap siswa diwajibkan menyusun huruf hinga menjadi sebuah kata yang disesuaikan dengan topik yang disepakati. Berikutnya, tahap kedua setiap siswa diminta menuliskan kata yang disebutkan pada kertas yang telah diberikan. Dengan tahapan ini akan membantu siswa untuk mengenal huruf, mengenal kata, maupun proses membaca pada susunan kata yang tersedia di papan scrabble. Sebagaimana penelitian Saadah (2019) yang mengungkapkan bahwa pembelajaran dengan memanfaatkan media permainan dapat memberikan dampak signifikan terhadap penambahan dan penguasaan pada kosakata.

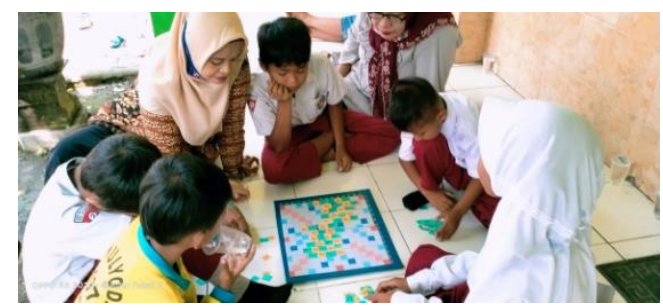

Gambar 3. Penerapan Scrable yang sudah dimodifikasi

Hal yang sama untuk kegiatan permainan scrabble, juga dibagi menjadi dua tahap. Tahap awal siswa menyusun huruf untuk dijadikan sebuah kosa kata dan dibantu dengan kata kunci. Siswa diminta untuk membaca kosa kata yang telah tersusun pada papan scrabble. Pada tahap kedua siswa diminta untuk menyimak shadow teacher / guru pendamping yang sedang membacakan sebuah teks, kemudian siswa mengulang apa yang didengarnya, dan di minta menyusun ubin huruf pada papan scrabble kemudian siswa membacanya kembali. Berdasarkan pembelajaran dengan menggunakan permainan scrabble yang telah dilakukan oleh siswa, scrabble sebagai sarana pembelajaran tidak memberikan pengaruh secara signifikan terhadap peningkatan kemampuan siswa untuk membaca. Ada beberapa siswa yang masih dalam taraf mengenal huruf sehingga ketika menyusun huruf menjadi kata dan membaca masih kesulitan. Selain pemberian permainan scrabble peneliti memberikan motivasi dan dukungan positif agar siswa mempunyai minat dan kemampuan membaca lebih baik.

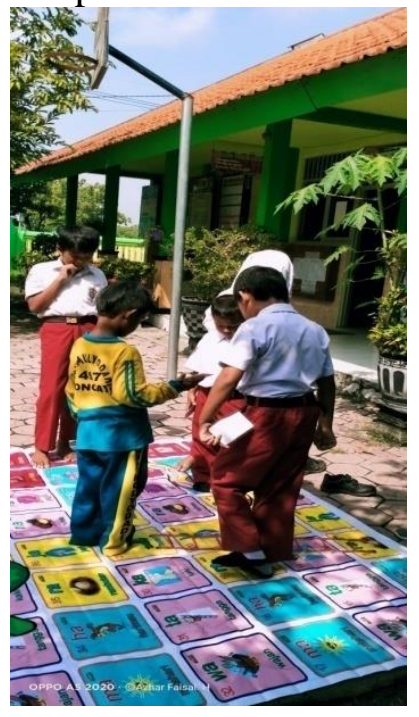

\section{Gambar 4. Penerapan Permainan Petualangan maharaja}

Pada permainan Petualangan Maharaja, siswa bermain menggunakan metode multisensori yaitu sebuah strategi dengan menggunakan modalitas yang dimiliki siswa untuk belajar. Strategi ini membimbing siswa menggunakan 
seluruh indera pada tubuhnya untuk melakukan permainan ini dengan cara merangkai kata menjadi sebuah kalimat kemudian diberi stimulus visual berupa flashcard yang bergambar dan stimulus auditoris bagi siswa untuk mengucapkan kata dan menghasilkan sebuah bunyi sesuai dengan kata yang ada pada kartu kata yang dipegang siswa. Perangsangan kinestetik dilakukan dengan cara siswa berjalan diatas arena alat peraga Petualangan Maharaja sambil

menyanyikan lagu "Maharaja" dan berhenti pada kotak sesuai dengan kartu yang dipegang, untuk mengeksplore dan meningkatkan motivasi siswa dalam kemampuan membaca banyak berbagai permainan dalam petualangan maharaja ini. Karenapembelajarannya bersifat permainan jadi anak lebih antusias dalam mengikutinya, sehingga anak lebih cepat termotivasi untuk belajar membaca.

Berdasarkan hasil kegiatan bermain petualangan maharaja didapatkan bahwa permainan tersebut memberikan pengaruh secara signifikan pada kemampuan membaca siswa disleksia. Selama permainan berlangsung, siswa bermain petualangan maharaja dengan menikmati permainan dan sangat gembira karena mereka bisa berjalan diatas matras yang full colour dan bebas ber ekspresi sesuai keinginannya. Membuat hati anak senang, nyaman sehingga tidak terasa bahwa dia sedang belajar. Bahwa dalam proses bermain sambil belajar dengan menggunakan metode multisensori (VAKT) dapat dilaksanakan dengan berulang kali dan berdampak pada kemampuan baca siswa dan menyusun kata dengan lancar serta tidak perlu waktu lama untuk mengeja.

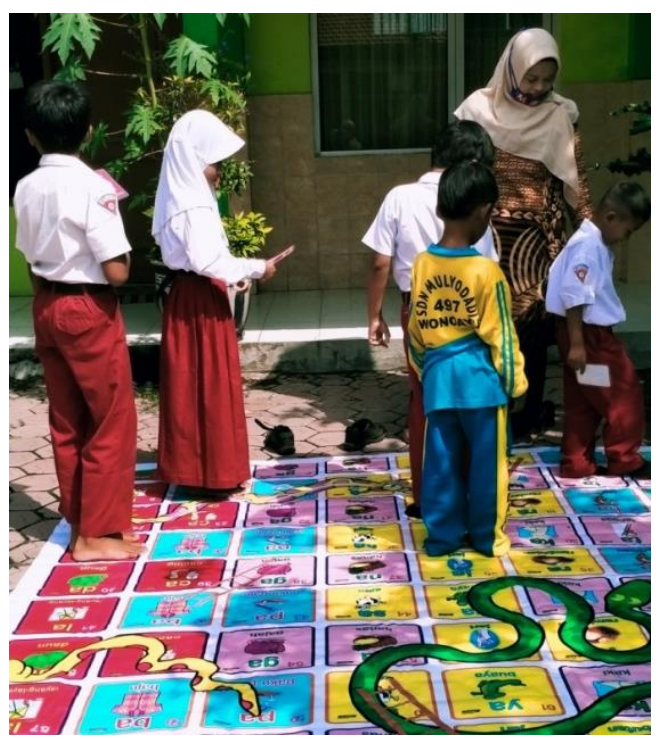

\section{Gambar 4. Penerapan Permainan Petualangan maharaja dengan shadow teacher}

Peningkatan kemampuan membaca siswa disleksia setelah belajar dan bermain petualangan maharaja serta pemberian motivasi pada siswa oleh pihak shadow teacher yang mendampingi dalam bermain, memberikan dampak semangat bagi siswa lebih ketika mengetahui akan mengikuti permainan ini walaupun siswa sendiri belum mengetahui bagaimana cara bermainnya dengan hanya melihat media yang begitu besar yang biasanya mereka bermain ulartangga yang medianya sebesar buku tulis. Satu diantara faktor yang penting dalam belajar adalah motivasi yaitu sebuah dorongan yang meningkatkan minat belajar siswa untuk membaca secara lancar dan mengurangi kesulitan belajar siswa. Motivasi 
belajar ini perlu dilakukan oleh orang tua/wali murid, karena dapat memberikan pengaruh minat belajar siswa yang menyandan disleksia. Selain memberikan media permainan petualangan maharaja, yang tak kalah penting adalah motivasi dan dukungan yang positif dari guru dan teman sebaya sehingga minat dan kemampuan membaca siswa dapat menjadi lebih baik.

Berbeda halnya dengan permainan scrabble terhadap peningkatan kemampuan membaca pada siswa disaleksia belum terlihat efektif, karena permainannya hanya monoton dalam menyusun huruf menjadi kata yang sesuai dengan kata kunci yang telah disebutkan oleh guru pendamping atau shadow teacher, siswa di tuntut memiliki kosakata lebih seperti contoh kata kunci hewan gajah nah siswa diminta menyusun nama hewan sesuai huruf yang ada baik mendatar, menurun atau menyilang seperti permainan teka teki silang. Selama proses permainan siswa juga sangat antusias dan mengikuti secara seksama permainan scrabble ini, dan tentunya ada yang masih dalam tahap mengenal bentuk huruf yang berbeda, pengucapan huruf dan belajar kosa kata terkadang siswa mengumpulkan huruf untuk kemudian disiapkan menyusun kata yang baru, namun karena kurangnya kosakata jadi seringkali kurang baik hasilnya.

Pengaruh permainan scrabble terhadap peninggkatan kemampuan membaca pada siswa disleksia dianggap kurang efektif disebabkan kurangnya motivasi yang berasal dari orang tua dan siswa itu sendiri. Ada beberapa siswa menganggap permainan scrabble itu sulit karena siswa harus mnguasai banyak kosakata, selain itu motivasi orang tua yang kurang mendukung ketika anak belajar dirumah tanpa didampingi, karena kesibukan orangtua, sehingga siswa belajar mandiri. Kekurangan siswa disleksia terutama dalam kemampuan membaca, dapat diperbaiki dengan membantu belajar membaca serta dalam evaluasi belajar siswa tersebut. Peran orang tua sangat di butuhkan khususnya dalam belajar membaca bagi siswa disleksia.

Ketika kedua permainan ini diterapkan baik scrabble dan petualangan maharaja, semua siswa memperoleh motivasi serta feed back yang positif oleh shadow teacher berupa pujian atas keberhasilan menyusun kata dan dapat membaca dengan baik. Hal ini seperti yang dikemukakan dalam penelitian Saadah ( 2019). Untuk memotivasi siswa dalam meningkatkan kemampuan membaca, siswa memerlukan feed back positif dari setiap keberhasilan yang diraihnya (Rahim, 2008). Permainan Scrabble dan pertualangan maharaja dibuat agar siswa disleksia mudah untuk membaca dan mau mengikuti acara penelitian ini, aturan kedua permainan ini membuat siswa terbantu dalam belajar huruf, belajar kosakata, serta memperbaiki kemampuan membaca.

\section{SIMPULAN DAN SARAN}

\section{Simpulan}

Berdasarkan uraian analisis data dan pengujian hipotesis serta dipaparkan dalam pembahasan penelitian, maka dapat disimpulkan bahwa:

1. Ada pengaruh perbedaan permainan scrabble versus 
petualangan maharaja terhadap kemampuan membaca siswa penyandang disleksia.

2. Ada pengaruh perbedaan motivasi tinggi dan motivasi rendah terhadap kemampuan membaca anak disleksia.

3. Ada interaksi antara permainan dan motivasi terhadap kemampuan membaca anak disleksia.

\section{Saran}

ajukan adalah:

Adapun saran yang kami

1. Perlunya dukungan dari sumber motivasi utama yang di dapatkan dari orang-orang terdekat baik orang tua atau warga sekitar, karena motivasi dalam mem baca siswa disleksia sangat mempengaruhi tingkat keberhasilan siswa dalam membaca

2. Dalam permainan petualangan maharaja sangat di tuntut keterampilan guru

pendamping maupun orang tua, karena dalam menerapkan permaian ini pada siswa ada kalanya tidak bisa diam, dan unsur permaian cenderung kinestetik.

\section{DAFTAR RUJUKAN}

Abdurahman, M. (2009). Pendidikan Bagi Anak Berkesulitan Belajar. Rineka Cipta.

Arikunto, S. (2014). Prosedur Penelitian Suatu Pendekatan Praktik. Rineka Cipta.

Diba, T. Z. (2019). Aku Disleksia. CV Andi.

Elbro, C. (2010). Dyslexia as Disability or Handicap: When Does Vocabulary Matter?
Journal of Learning Disabilities, 43, 469-478.

https://doi.org/10.1177/0022219 409357349

Hinebaugh, J., P. (2009). A Board Game Education. Rowman \&Little field Education.

Ismail, A. (2009). Education Games. Pro-U Media.

Mulyono, A. (2012). Anak Berkesulitan Belajar Teori, Diagnosis dan Remidiasinya. Rineka Cipta.

Rahim, F. (2008). Pengajaran Membaca di Sekolah Dasar. Bumi Aksara.

Saadah, V. N., \& Hidayah, N. (2019). Pengaruh Permainan SCRABBLE Terhadap Peningkatan Kemampuan Membaca Anak Disleksia Emphati. Jurnal Fakultas Psychology, 1(1). http://journal.uad.ac.id/index.php /EMPATHY/article/view/3000

Sari, T. (2013). Meningkatkan motivasi Belajar Anak Disleksia Untuk Mengurangi Kesulitan Belajar Membaca. Proseding Seminar Nasional PGSD UPY Universitas PGRI Jogyakarta.

Soeisniwati, L. (2012). Disleksia Berpengaruh Pada Kemampuan Membaca Dan Menulis. Jurnal STIE Semarang, 4(3).

Zunus, T. P. (2017). Metode Fernald untuk meningkatkan kemampuan membaca pada anak disleksia. Jurnal Psikologi Universitas Muhammadiyah Malang. http://eprints.umm.ac.id/43371/1 /jiptummpp-gdl-zunustripr47298-1-zunus20-6.pdf 